\title{
HENRY A. KISSINGER'S ARTICLE ON TERRORISM: A CRITICAL ANALYSIS
}

\author{
Mokhamad Toha Rudin \\ Muhammadiyah University Surakarta \\ mtoharudin@yahoo.co.id
}

\begin{abstract}
The aim of this study is to conduct a critical analysis of Kissinger's article "America's Assignment" on Newsweek 2004, and to elaborate US foreign policy toward Islam world and Terrorism after the end if the Cold War, this article also tries to find the ideology or tradition of American foreign policy reflected in Kissinger's article "America's Assignment", and how is Realism ideology reflected in the article. The study employs library research in which the data gathered from books, journals, magazines, and internet. The study also employs Van Dijk's critical linguistic model for the critical analysis of Kissinger's "America's Assignment".

The result of the study shows that Kissinger's "America's Assignment" reflects both "multilateralistrealist" and "realist-idealist" perspectives for the US foreign policy that the US government should employ. He argues that no single superpower in the world could manage the world order alone without the participants of other world countries. He opposes W. Bush's unilateral foreign policy toward Iraq though he agrees to "the move toward empire (terrorist) must be halted immediately". He also argues that bringing democracy into the world, especially Iraq and Muslim worlds, is necessary in order to set up the new world order. The study also shows that after the collapse of the Soviet Union, there is a new ideological and cultural conflict between Islam, especially the militant fundamentalist in the fringe of Islam, against the US (Western) globalization of democratization. The new conflict is also generated by the Western phobia toward Islam that can be traced back to the mid-century when the War of Crusade between Islam and Christianity happened.
\end{abstract}

Keywords: US foreign policy, Realist, Idealist, Multilateralist, Unilateralist

\section{INTRODUCTION}

The United States is recognized as a country that embraces liberal democracy that includes democratic principle in its politic, capitalism in its economy, and individualism for its citizen-high appreciation of human rights of its people. Today, the United States is in a wholly new age of world affairs. For the
United States, it is an age which is both full with confusions and dangers, and with one major blessing that is no great-power rivalries threaten immediately the pace of the world. However, there are still some paradoxes in the United States role in international politics.

The United States wants to promote democratic values abroad, but also strengthens 
non-democratic governments, such as Saudi Arabia to secure its sources of energy. Then, the debate over US foreign policy revealed sharply contrasting conceptions of American interests (Burns, 1998: 555). After the terrorism of September $11^{\text {th }}$, the W. Bush's administration defined a new grand strategy whose main features were an unending war on international terrorism, preventive war, aggressive unilateral-ism, and a commitment to maintain US military supremacy (Barry, 2004: 1). Even Hoadly says that US foreign policy has become more activist and controversial, so that terms used to describe have become more varied and flamboyant. American policy abroad is now routinely charac-terized as not only unilateralist and arrogant, but also hegemonic, militaristic, exploitative, provocative of terrorism, and destructive of international order (Hoadly, 2003, p.1).

September $11^{\text {th }}$ has shacked the great power of the United States in international politic. Most its people and governments cursed on this event. This event is considered as humanity crime because the most numbers of its victims was common people or ordinary citizens. This event is also considered as the enemy of freedom, so the fight against terrorism is the fight of all who believe in progress and pluralism, and tolerance and freedom. So it is the world's fight. This provocative words of terrorism was reflected in

George W. Bush's speech in front of Joint Session of Congress (September 2001): “... This is not, however, just America's fight. And what is at stake is not just America's freedom. This is the world's fight. This is civilization's fight. This is the fight of all who believe in progress and pluralism, and tolerance and freedom. The civilized world is rallying to America's side" (Heffner, 2002, p.526).

Particularly, the study intends to know and demonstrate that Kissinger's article of “Ameri-ca’s Assignment” on Newsweek 2004 contains the war against terrorism issue as a reflection of the American tradition of realism in its foreign policy. Realism and Real politic is foreign policy based on practical and selfinterest factors rather than on moral, idealistic, or theoretical considerations. Realists say that the United States should intervene in world affairs only if its vital interests are in jeopardy or if a dispute involves overt outside aggression, not simply internal rebellion (Burns, 1998, p.557). Political Realism is one of relevant perspectives to see American foreign policy. In political Realism, referred to Morgenthau (1962), American foreign policy can be discriminated into three categories: 1) Imperialism, which tends to change political 
structure or regime authority; 2) Status Quo, which tends to defend the existing political structure; and 3) Prestige, which tends to execute and promote power and strength to support those two categories (Siswanto, 1999, p.83).

The study intends to know and discuss that Kissinger's article of "America's Assignment" is a reflection of realism ideology. So the problem of the study can be stated as the following:

1. What is the ideology reflected in Kissinger's article of “America's Assignment"?

2. How is Realism ideology reflected in this article?

3. How is the American Foreign Policy toward Islam after the collapse of the Soviet Union?

\section{CRITICAL DISCOURSE ANALYSIS (CDA) FRAMEWORK}

Discourse has various meanings in the sense that many different disciplines and fields have their own definitions and scopes. The term of discourse is used in the fields, such as language, psychology, sociology, politic, communication, literature, etc. Discourse, in linguistics, means language in use, as opposed to language as an abstract system. It also means that what is possibly said about one or more topics within the constraints of a given time, place, or social, cultural, or institutional setting. Discourse can be defined as a verbal expression in speech or writing, a verbal exchange that is conversation, a formal lengthy discussion of a subject, either written or spoken form, and the process or power of reasoning.

There are many approaches to discourse analysis, rooted in different disciplines. The approach will be concerned with the discourse analysis that is, based on a close examination of language in use, that seeks to illuminate the significance and implications of social, cultural, historical, and political practices. A particular concern of this approach will be the ways in which discourse functions within institutions, especially the media.

Approaches in Critical Discourse Analysis of texts of media are also varied. There are many models of discourse analysis proposed by some experts, such as Sara Mills, Teun A. van Dijk, and Norman Fairclough. Although each of them has its own patterns and features, they share commonness in some aspects. Those models consider: 1) that ideology is a central part of the analysis, ideology and power are 
always employed to determine the grammatical and syntactical choices of a text or discourse. It is also said that ideology is always contained in all texts virtually or unvirtually, diction, sentence, and grammar reflects that ideology; 2) that power has central role in the analysis, discourse can strengthen and widen the power influences. Each group of society has less or more power, so that the more powerful will play more roles in defining the discourse. Thus, there will be more or less dominant discourse; 3) that discourse can be manipulated by the more powerful to increase and broaden the dominance over the dominated or to marginalize less powerful group of society. So that the discourse analysis intends to analyze how the dominant discourse defines and describes the dominated group; 4) that discourse analysis uses language does not represent things as what they really are, but has been influenced by the more powerful group's ideology which has certain goals or purposes. Discourse analysis treats language in relation to social practices, it does not only focus on the study of linguistics, but also on the study of language usage in social perspectives (Eriyanto, 2001, p.342-343).

\section{a. Van Dijk's Model: a Critical Discourse Analysis}

Teun A. van Dijk's Model of Critical Discourse Analysis is also called "Social Cognition". This model is mostly used by researchers (Eriyanto, 2001, p.221). That is why this study is conceptualized under this Social Cognition in the analysis. Teun A. van Dijk's analytical framework differs from that of Fairclough. Van Dijk's schematic and method of research uses an integrated analysis which covers: 1) texts structure; 2) social cognition; and 3) social context (Eriyanto, 2001, p.224). Teun A. van Dijk's method in research can be described as follows:

\begin{tabular}{|l|l|}
\hline \multicolumn{1}{|c|}{ STRUCTURE } & \multicolumn{1}{c|}{ METHOD } \\
\hline $\begin{array}{l}\text { Text: to analyze the discourse strategies used in describing a person } \\
\text { or an event and in marginalizing or negating a certain group, idea, } \\
\text { or event }\end{array}$ & Critical Linguistics \\
\hline $\begin{array}{l}\text { Social Cognition: to analyze journalist's cognition in understanding } \\
\text { a person or an event to be written }\end{array}$ & Depth Interview \\
\hline $\begin{array}{l}\text { Social Analysis: to analyze the discourse that exist in society; the } \\
\text { process of production and reproduction in describing person or } \\
\text { event }\end{array}$ & $\begin{array}{l}\text { Library research in social and } \\
\text { historical perspectives }\end{array}$ \\
\hline
\end{tabular}

Adapted from Eriyanto (Eriyanto, 2001, p.275) 


\section{CRITICAL ANALYSIS OF KISSINGER'S ARTICLE: “AMERICA'S ASSIGMENT”}

\section{b. Profile: Henry A. Kissinger}

Dr. Henry Alfred Kissinger was born in Fuerth, Germany, on May $27^{\text {th }}, 1923$. He came to the United States in 1938, and was naturalized a United States citizen on June $19^{\text {th }}, 1943$. He received the BA Degree Summa Cum Laude at Harvard College in 1950, and the MA and Ph. D Degrees at Harvard University in 1952 and 1954 respectively. He was the $56^{\text {th }}$ secretary of State of the United States from 1973 to 1977 , continuing to hold the position of Assistant to the President for National Security Affairs, which he first assumed in 1969 until 1975. He was one of the first to react to the recent tragedy of terrorism. "Those who provide support, financing, and inspiration to terrorists are as guilty as the terrorists themselves" (Kissinger, 2004, p.5), he intoned. These were the words that Walker Bush would repeat hours later.

\section{c. The Main Message of Kissinger's "America's Assignment"}

It is an illusion that the current international relation is a world without conflict. In the aftermath of $9 / 11$, the beginning challenge for the US primacy has begun. Terrorism was emerging as a threat to the global equilibrium. Moreover, countries that develop nuclear weapons have also become new threats as their sovereignty in nuclear proliferation and advances threaten the safety of the global world. Kissinger says, "The contemporary security challenge arises from two unprecedented sources: terror caused by acts until recently considered a matter for internal police forces rather than international policy, and scientific advances and proliferation that allow the survival of countries to be threatened by developments entirely within another state's territory" (Kissinger, 2004, p.30).

However, the challenge or threat of international order does not only come from terrorists, but also from nuclear proliferation. The international system is now confronted by the imminent spread of nuclear weapons into the hands of two countries with a worrisome agenda, namely: North Korea and Iran. North Korea is responsible for assassinations, kidnappings, and a rouge regime. Similarly, Iran has held American diplomats as hostages and has supported a variety of terrorist groups in the Middle East and continuous to declare America as its principal enemy (Kissinger, 2004, p.33). 


\section{d. The Analysis of Kissinger's \\ "America's Assignment"}

Realism is very influential to the American foreign policy. The roots of realism can be traced back to the era of some philosophers, such as Thucydides and Santo Augustine. Henry A. Kissinger calls it as geopolitics. Realism pessimistically views humankind as wicked and evil, so that no people institution could manage them. The struggle for power becomes the eternal political dimension of human life, especially in the term of relations among nations. No nation could solve the conflict in international relations. Each nation has its own power interest and each struggle to preserve the power. Consequently, the global relation is always in caseless conflict. Morgenthau says that international politic is the struggle for gaining power and so is foreign policy of each nation (Minderop, 2006, p.131-132). As realism focuses on the shifting distribution of power among the states, its core belief is that international affair is a struggle for power among self-interested states. Hence, nuclear sighted states can mitigate the causes of war by finding ways to reduce the danger they pose to each other. Although it seems that the September 11 tragedy has weakened this perspective, the realist can explain that when a state grows vastly more powerful than any other opponent, it will eventually use that power to expand its sphere of domination (Snyder, 2004, p.55).

In his "America's Assignment", Kissinger assertively confirms that notion above. In the first part of his article, he says the world today is in the threat of the new coming challenges coming from the terrorists, the fundamentalist militant fringe of Islam, and two countries which develop and proliferate nuclear weapons, such as North Korea and Iran, they are considered as a threat to the current international order, since they have worrisome agenda in which North Korea is responsible for assassinations, kidnappings, and a rogue regime, and Iran has held American diplomats as hostages and has supported a variety of terrorist group in the Middle East and continuous to declare America as its principal enemy (Kissinger, 2004, p.33). His perspective on "America's Assignment" could also be called "idealist-realist". It is in the sense that he agrees with Walker Bush's war on Iraq and democratization of Iraq. Kissinger agrees with the US dominant military approach in the global war on terror. It can be discerned that the dominant interpretation of terrorism as an external phenomenon located in haven states. As realism generally highlights states as the relevant actors in the world politics and neglects other actors, so the 
necessity in dealing with the rise of terrorism is to trace translational terrorism back to the state. The construction of haven states is the best way to achieve. Iraq, then, becomes the target of this construction theory. What Kissinger rejects is that the war on Iraq is not appropriate, because of the current US intervention policies, and he argues that it will be a much more efficient approach by multinational cooperation and police coordination.

Kissinger's idealism comes in when he refers to democratization of Iraq. Promoting the spread of democracy was a genuine interest of idealists, such as Wilson. So that Kissinger has changed his old ideas of realism turned into the amalgam of realism and idealism. His controversial idea is reflected in his statement about democratization in Iraq, as he says, "The effectiveness of Iraqi forces will depend not on their military training, but on the degree to which the emergence of institution gain domestic legitimacy. Democracy must not be seen as a suicide pact by the Sunnis and Kurds" (Kissinger, 2004, p.32). The multilateralists can be the idealists or realist managers (Kissinger, 2004, p.33) - have little influence over the US foreign policy in the contemporary era. Indeed, until there is a change of administration in Washington it is unlikely that the United States to harness its 'soft power' is likely to go unheeded. In the meantime, the language of Bush's foreign policy is replete with the pro-active rhetoric of Wilsonian democratic imperialism. The argument of the unilateralist idealist finds its fullest articulation in contemporary US policy in Iraq. Based on the sociological perspective, "America's Assign-ment" is a rhetorical argument for the US policy toward Middle East, especially Iraq, with terrorism stereotyping. It is the US "assignment" to build international order by destroying and attacking Iraq (terrorist state) that was dominated by the majority of Sunni Muslims. Regardless of the victims of the attack, Kissinger claims that it is "assignment" and not "the act of terror" by the US, although many civilians, who innocence, become suffered victims of the attack; some were injured, disabled, and some others were dead. Even the suffered people were could be more than those of the victims of September 11. Implicitly, Kissinger tries to build a discourse that marginalize Muslims, especially Sunni Muslims, by labeling them with "terrorists" who has become a threat and enemy of the current dominant order under the superpower, the United States. Kissinger says that Sunni Muslims are terrorists and they are dangerous, especially in Iraq, that they could be more destructive when they are in power. In order to save the world, he proposes democracy should 
replace the dominant power of Sunni Muslims, because he thinks that "the basic adversary is the radical fundamentalist militant fringe of Islam, which aim to overthrow both moderate Islamic societies and all others, it perceive as standing in the way of restoring an Islamic caliphate. ...If radical government emerges at Baghdad - because the United is defeated ... even more if Iraqi falls into terrorist chaos - the entire Islamic world will find itself in turmoil" (Kissinger, 2004, p.31). Consequently, the insurgency in the Sunni region is not only a national struggle against America, it is a means to restore political dominance in Iraq. Kissinger marginalizes Islam by labeling caliphate system as a terrorist system that would always discriminate non-Muslims. It is not universal system, he thinks, that does not emulate to "Federalist structures and the assurance that free speech of conscience, and due process of law are constitutionally beyond the reach of any majority might provide some guarantee for the concerns of the various groups and a safety net..." (Kissinger, 2004, p.32). In other words, he says that "Islam is terror and fierce, but democracy is safety and universal world order".

In brief, the ideology behind this text is to have world people brainwashed with the notion that American's attack to Iraq represents "the act of the trustee global stability" (Kissinger, 2004, p.31) against terrorists, especially terrorists sanctuaries in Iraq. The US is the world leader of internationalization - where, Kissinger calls it, America's Assignment. This ideology is also a dominant latent meaning of the text that tends to marginalize Islam. It also means that Newsweek has the same ideology as the US government, especially for international terrorism that is always referred to Muslims. Meanwhile terrorism is actually a phenomenon, which has not only happened and conducted by Muslims, but also some other groups all over the world. In brief, the ideology behind this text is to have world people brainwashed with the notion that American's attack to Iraq represents "the act of the trustee global stability" (Kissinger, 2004, p.31) against terrorists, especially terrorists sanctuaries in Iraq. The US is the world leader of internationalization - where, Kissinger calls it, America's Assign-ment. This ideology is also a dominant latent meaning of the text that tends to marginalize Islam. It also means that Newsweek has the same ideology as the US government, especially for international terrorism that is always referred to Muslims. Meanwhile terrorism is actually a phenomenon, which has not only happened and conducted by Muslims, but also some other groups all over the world. Politically and 
sociologically those who have conducted the acts of terror, were the product of injustice gap, which is as a result of what Kissinger calls the world order that is being tried to be built by the US.

\section{e. American Foreign Policy}

American foreign policy comprises the goals that the nation's officials seek to attain abroad, the values that give rise to those objectives, and the means or instruments through which they are pursued. American foreign policy is in terms of persistent goals and somewhat more variable tactics (Kegley, Jr., 1982, p.34). American foreign policy has shown a capacity for adaptation in pursuit of established objectives. It can be seen in the foreign policy of some early American Presidents.

Realism and idealism are both continuous traditions in American diplomatic history. They compete to each other as conceptions of how the US ought to define its foreign policy objectives, even while they coexist with one another. While one tradition may predominate over the other at any single point in time, neither has managed to obliterate the influence of the other (Kegley, Jr., 1982, p.80). Then the duality they endanger accounts for the willingness of the US at times to sacrifice its cherished ideals for an expedient action, even while reaffirming its ideals and promoting their maintenance. Moral idealism assumes that politics is affected by the fact that human beings are essentially "good" and capable of altruism and cooperation; bad or wicked behavior is the result, not of bad people, but of bad institution which breed such behavior (Kegley, Jr. 1982, p.77).

\section{f. The United States and the World of Islam after the Collapse of Soviet Union}

Some say that after the fall of Soviet Union, America needed a new enemy in order to get a new challenge as the counter-balance power. It is because international relations among world countries is an anarchic environment in which each countries seeks to struggle for power and the world has no single authority that can rule and govern world countries into harmonious relations. Then some views emerge in dealing with the future of American foreign policy after the end of the Cold War. The most dominant discourse of international relations after the end of Cold War has been represented on the contrasting global political vision of the Huntington's thesis of "Clash of Civilization" against Fukuyama's thesis of "The End of History". On the one hand, Huntington's paradigm organized the world into conflicting 
zones with the culture replacing ideology. Francis Fukuyama's "The End of History" posited that the world would see a growing zone of stable liberal democracy and integrating market capitalism - called as globalization. Then, the backlash against globalization and against American hegemony has become one of the defining characteristics of the present world on the other.

Huntington has warned that the West and the US should keep their eyes on the growth and development of Islam. He thinks that the growth and development of Muslim will cause instability in both Muslim society and the West or the US. The great number of young Muslim with higher education will strengthen the revival of Islam, its militancy, its militarism, and immigration to the West. In this early century, the revival of Islamic force and culture has appeared and caused a clash with the West. Recently, some groups of militant Muslims have become the primary threat or enemy to the West and have replaced the role of the Soviet Union as the counterbalance power of the US. This "new war" between militant Islam and America has many similarities to the Cold War.

\section{g. Terrorism and the United States of America in Post-Cold War}

The end of the Cold War left the United States as the only great superpower. Some authors like Samuel Huntington stressed the importance of the US unique role, with its "primacy". In the international relations, primacy is acquired when a particular state has the capacity to shape decisions that affect the world. In Huntington's argument, only the United States possesses the power and the necessary values to support a prosperous, increasingly democratic, and stable international order (Contreras, 2003: 7). It was the end of everything; the end of communism, of socialism, of the Cold War, of the European wars. But the end of everything was also a beginning. On December 26th, 1991, the Soviet Union died and something new was born, that is a unipolar world dominated by a single superpower unchecked by any rival and with decisive reach in every corner of the globe (Krauthhammer, 2004, p.1).

After the event of 9/11, United States foreign policy has become so activist and controversial. Terms used to describe it have become more varied and flamboyant. American policy abroad is now routinely characterized as not only unilateralist and arrogant, but also hegemonic, militaristic, exploitative, provocative of terrorism, and destructive of international order. 
Every nation/people really hope to have peace and safety in the world. Unfortunately, each nation/people has its own interest and power so that the conflict among nations could be avoided. The tendency to have war against each other is also unavoidable or inevitable. The most possible thing to do is to prevent nations or countries of the world from war. In case a war happens, the right thing to do is to manage to end the war, to have peace agreement for the countries involved in the war, to have justice and truth that can be approved, and to have no war victims anymore.

\section{REFERENCES}

Barry, Tom. Ed. (2004). Toward a New Grand Strategy for the US Foreign Policy. IRC Strategic Dialogue No. 3. International Relation Center. www.irc-online.org, People-Centered Policy Alternatives, since 1979.

Contreras, R. G., (2003). American Unilateral ism and the Doctrine of Preenption: the Case of Iraq. Denver: University of Denver.
Eriyanto, (2001). Analisis Wacana: Pengantar Analisis Teks Media, Yogyakarta: LkiS.

Fukuyama, Francis. (2006). The Clash of Cultures and American Hegemony. Retrieved from http://www.theamerican-interest.com/ai2/article.cfm? $\mathrm{Id}=178 \& \mathrm{MI} \mathrm{d}=1$ )

Hoadly, S., (2003). Characterising US Foreign Policy. Centre for Strategic Studies ISSN 1175-1452 CSS Strategic Briefing Papers Volume 5: Part I.

Kegley, Jr., Charles W., \& Eugene R. W., (1982). American Foreign Policy: Pattern and Process, New York: St. Martin's Press, Inc.

Kissinger, Henry A., (2004). America's Assignment. Newsweek, November 8, 2004.

Krauthammer, Charles, Democratic Realism: An American Foreign Policy for a Unipolar World, American Enterprise Institute, the International Relations Center. Peoplecentered policy alternatives since 1979 , 2004. (http://www.aei.org/docLib/2004 2007_book755text.pdf)

Siswanto, (1999). Kebijakan Amerika dan Indonesia terhadap Timor Timur dalam Perspektif Containment Policy, Jakarta: Pusat Kajian Wilayah Amerika, Universitas Indonesia.

Snyder, J., (2004). One World, Rival Theories, Columbia: Columbia University.

Wilson, Stan Le Roy, (1995). Mass Media/Mass Culture: An Introduction, Carolina: McGrowhill, Inc. 
